\title{
Coping strategies and relation with depression levels of mothers of children with congenital heart diseases
}

\section{Doğuştan kalp hastalığı olan çocukların annelerinin baş etme tutumlarının depresyon düzeyleri ile ilişkisi}

\author{
PInar ERASLAN ${ }^{1 *}$, Sercan TAK²
}

'Presidential Medical Unit, Psychiatry Outpatient Clinic, Ankara/TURKEY

${ }^{2}$ Dr. Sami Ulus Gynecology Obstetrics and Child Health and Diseases Training and Research Hospital, Department of Pediatric Cardiovascular Surgery, Ankara/TURKEY

\begin{abstract}
Aim: To reveal the coping attitudes of mothers of children who had undergone surgery to diagnose congenital heart diseases and the relationship between these attitudes and depression levels.

Material and Methods: This study was a cross-sectional observational descriptive study conducted in a pediatric cardiovascular surgery clinic. The study included 32 mothers of pediatric patients who were surgically treated for congenital heart diseases. Participants were assessed with sociodemographic information form, Turkish versions of the coping orientation to problems experienced inventory (COPE), and the Beck depression inventory (BDI).
\end{abstract}

Results: The median maternal age was 31.0 (range, 21-47) years. The median BDI score was 11 (range, 1-27), and the number of mothers with a BDI score of 17 and above was 13 (40.6\%). Problem-focused coping was the most common problem-coping style used by 29 (90.6\%) participants with a median score of 67.0 (range, 41.0-72.0). In addition, 10 (31.3\%), $10(31.3 \%)$, and $9(28.1 \%)$ participants showed the highest scores for active coping, suppression of competing activities, and seeking instrumental social support subscales, respectively. There was a negative correlation between BDI score and active coping, restraint, seeking instrumental social support subscales, and problem-focused coping total scores.

Conclusion: Our study revealed that most mothers of children with CHD used problem-focused coping more frequently. There was a negative correlation between the problem-focused coping attitude total score and the Beck Depression total scores. Interventions to target problem-focused coping could potentially protect mothers from depression.

Keywords: Coping strategies; mother; congenital heart diseases; depression 


\section{Öz}

Amaç: Doğuştan kalp hastalığı (DKH) tanısıyla ameliyat olan çocukların annelerinin baş etme tutumlarını ve bu tutumlar ile depresyon düzeyleri arasındaki ilişkiyi ortaya çıkarmak.

Gereç ve Yöntemler: Bu çalışma bir pediatrik kardiyovasküler cerrahi kliniğinde yürütülen kesitsel gözlemsel tanımlayıcı bir çalışmadır. Çalışmaya DKH tanısı ile cerrahi olarak tedavi edilen pediatrik 32 hastanın annesi dahil edildi. Katılımcılar sosyodemografik bilgi formu, Baş Etme Tutumları Ölçeği (COPE) Türkçe versiyonu ve Beck Depresyon Ölçeği (BDÖ) ile değerlendirildi.

Bulgular: Ortanca anne yaşı 31.0 (aralık, 21,0-47,0) yıldı. Ortanca BDÖ puanı 11 (aralık, 1-27), BDÖ puanı 17 ve üzeri olan anne sayısı 13 (\%40,6) idi. Sorun odaklı başa çıkma, 29 (\%90.6) katılımcının, ortanca 67.0 (aralık, 41.0-72.0) puanla, kullandığı en yaygın baş etme tutumu olmuştur. Ayrıca $10(\% 31,3), 10(\% 31,3)$ ve $9(\% 28,1)$ katılımcı sırasıyla aktif baş etme, diğer meşguliyetleri bastırma ve yararlı sosyal destek kullanımı alt ölçeklerinde en yüksek puanları göstermiştir. BDÖ puanı ile aktif baş etme, geri durma, yararlı sosyal destek kullanımı alt ölçek ve sorun odaklı başa çıkma toplam puanları arasında negatif bir ilişki vardı.

Sonuç: Çalışmamız, DKH'li çocuğu olan annelerin çoğunun sorun odaklı başa çıkmayı daha sık kullandığını ortaya koydu. Sorun odaklı başa çıkma tutumu toplam puanı ile BDÖ toplam puanları arasında negatif bir ilişki vardı. Bu ilişki göz önüne alınarak sorun odaklı başa çıkmayı hedefleyen müdahalelerin anneleri potansiyel olarak depresyondan koruyabileceği düşünülebilir. Bu konuyu araştırmak için geniş çaplı yeni çalışmalara ihtiyaç vardır.

Anahtar Kelimeler: Başa çıkma stratejileri; anne; doğuştan kalp hastalıkları; depresyon

\section{Introduction}

Congenital heart disease (CHD) is one of the most common causes of infant admission to pediatric intensive care, infant mortality, and disease-related disability in children under five years of age [1]. The different types of CHD vary widely in clinical manifestations, severity, treatment variability, length, and invasiveness. Especially in the last two decades, advances in diagnostic, medical, and surgical techniques have significantly increased the survival rates of children with CHD [2].

Many stages of the disease and treatment, being diagnosed, fear of future disability or death, hospitalizations (which may require separation from the baby), waiting for surgery, and post-operative recovery, can be a traumatic process for both families and babies [3]. Parents of children with $\mathrm{CHD}$ are at risk for psychiatric conditions such as traumatic stress, depression, addictions, and suicide [3]. After discharge from hospital, parents of children become vigilant about the child's health [4]. Especially mothers are at risk for adjustment difficulties [4]. It was shown that mothers of children with CHD expressed several difficulties during the hospitalization process [5]. Mothers with high levels of fear and distress may have difficulty in providing the child with CHD with the attention and care they need, and conversely, psychological distress in the child due to CHD may further increase the mother's distress [6]. Studies show that skill-based, informative and supportive approaches aimed at improving mental health in parents of children with chronic medical conditions also reduce anxiety, depression, and acute stress symptoms in parents of children with CHD [7]. Knowledge and active coping skills are protective factors for adaptation in mothers of infants with CHD [8].

It is a universal attitude to use some coping styles to minimize or eliminate the negative effects of stressful events or factors [9]. Effective coping attitudes protect the individual against cognitive, environmental, and biological factors that cause distress [9]. Coping attitudes are divided into three as problem-focused coping, emotional-focused coping, and less useful coping styles [10]. Some studies have found a negative relationship between problem-focused coping methods and Beck Depression Inventory (BDI) scores and a positive relationship between less useful coping methods and BDI [10].

There are few studies in the literature investigating coping methods used in mothers of children with CHD. In this study, we aimed to investigate the coping attitudes of mothers of children who had under gone surgery with a diagnosis of CHD and the relationship between these attitudes and depression levels.

\section{Material and Methods}

This study was a cross-sectional observational descriptive study. Mothers of children who were treated surgically between November 2019 and March 2021 in the pediatric cardiovascular surgery clinic of UHS Ankara Dr. Sami Ulus Gynecology Obstetrics and Child Health and Diseases Training and Research Hospital were included in the study. Participants who had at least primary education and were not currently receiving any treatment for a psychiatric disorder were included in the study. Participants were asked to fill out the 
sociodemographic information form, the Turkish version of the Coping Orientation to Problems Experienced (COPE) Inventory, and the Turkish version of the Beck Depression Inventory (BDI). All the forms used in the study were given in print and filled in by the participants themselves. The study was conducted after local ethics committee approval (UHS Dr. Abdurrahman Yurtaslan Ankara Oncology Training and Research Hospital Ethics Committee, Document No: 2019-11 / 459, Date: 20.11.2019) and all participants signed the informed consent form before inclusion in the study.

\section{Instruments}

\section{Sociodemographic Information Form}

A constructed demographic information form included questions about age, age at which the child was diagnosed, number of children, marital status, educational status, employment status, comorbidities (i.e. diseases such as hypertension, diabetes mellitus, osteoarthritis, migraine), history of psychiatric illness.

\section{Beck Depression Inventory}

The Beck Depression Inventory measures the physical, emotional, cognitive, and motivational symptoms seen in depression. It is aimed to determine the degree of depressive symptoms objectively. The inventory consists of 21 questions, each of which scores between 0 and 3 [11]. High scores on this scale indicate an increase in the severity of depressive complaints [11]. Hisli et al demonstrated the validity and reliability of the Turkish version of the BDI and it was observed that a scale score of 17 and above was a level that determined depression above normal [12].

\section{Coping Orientation to Problems Experienced Inventory}

Carver et al. developed the COPE scale to determine coping methods used in the face of stressful life events [10]. The scale is a likert-type self-report scale consisting of 60 questions. It is answered through four options: $1=1$ usually don't do this at all, $2=$ I usually do this a little bit, $3=$ I usually do this a medium amount, $4=$ I usually do this a lot. COPE consists of 15 subscales: 1.Active coping, 2.Restraint, 3.Planning, 4.Seeking instrumental social support, 5.Suppression of competing activities, 6.Positive reinterpretation and growth, 7.Religious coping, 8.Humor, 9.Seeking emotional social support, 10.Acceptance, 11.Behavioral disengagement, 12.Substance use (Alcohol/drug use), 13.Denial, 14.Mental disengagement, 15.Focus on and venting of emotions. The total score that can be obtained from each subscale is between 4 and 16. The sum of the scores of the first 5 of these subscales gives the problemfocused coping score, the sum of 6-10 subscale scores gives the emotionally focused coping score, and the sum of the last five subscale scores gives the "less useful" coping score. Ağargun et al. demonstrated the validity and reliability of the Turkish form of the COPE scale [13].

\section{Statistical analysis}

Statistical analysis was performed using SPSS software (SPSS for Windows, version 24.0., SPSS Inc., Chicago, USA). Descriptive statistical methods were used to determine the main characteristics of the participants. Numeric data were presented as median (range), and categorical data were presented as frequency (percentage). Pearson correlation test was used for correlation analysis between BDI score and COPE subscale scores. All statistical tests were two-sided, and p-values of $<0.05$ were considered statistically significant.

\section{Results}

The mothers of 32 pediatric patients who were surgically treated for congenital heart diseases were included. Median maternal age was 31.0 (range, 21-47) years. All participants were married. Median age at diagnosis of the patients was 3.8 (range, 0-192) months. Eight of the patients (25.0\%) were of school age, and 16 (50.0\%) were girls. Ventricular septal defect, atrial septal defect, and both were observed in 11 (34.4\%), $6(18.8 \%)$, and $2(6.3 \%)$ patients, respectively, and were the most common cardiac etiologies. Of the mothers, 16 (50.0\%) were university graduates, and 7 (21.9\%) were working. Four (12.5\%) of the participants had a history of psychiatric disease and treatment. Median BDI score was 11 (range, 1-27), and the number of mothers with a BDI score of 17 and above was 13 (40.6\%). The main characteristics and BDI scores of the participants are shown in table 1.

Problem-focused coping was the most common problemcoping style used by $29(90.6 \%)$ participants with a median score of 67.0 (range, 41.0-72.0). Emotional-focused coping and less useful coping styles are the problem coping styles used primarily by $2(6.3 \%)$ and 1 (3.1\%) participants, respectively. Religious coping was the subscale with the most participants ( $n=28$, $87.5 \%)$, showing the highest score (median 16.0, range, 9.0-16.0). In addition, 10 (31.3\%), 10 (31.3\%), and 9 (28.1\%) participants showed the highest scores for active coping, suppression of competing activities and seeking instrumental social support subscales, respectively. There was a negative correlation between BDI score, and active coping, restraint and seeking instrumental social support, problem-focused coping scores. Median scores of the COPE subscales, which scale has the highest score for how many patients (i.e., the most frequently used subscale), and the results of the correlation analysis between the subscale scores and the BDI score are shown in Table 2. 


\begin{tabular}{|c|c|c|}
\hline Parameter & $\mathrm{n}$ & $\%$ \\
\hline Mother age, years, median (range) & 31.0 & $21-47$ \\
\hline $\begin{array}{l}\text { Age of patients at diagnosis, } \\
\text { months, median (range) }\end{array}$ & 3.8 & 0-192 \\
\hline Number of children, median (range) & 2.0 & $1-6$ \\
\hline \multicolumn{3}{|l|}{ Educational status } \\
\hline Primary school & 6 & 18.7 \\
\hline High school & 10 & 31.3 \\
\hline University & 16 & 50.0 \\
\hline \multicolumn{3}{|l|}{ Employment status } \\
\hline Yes & 7 & 21.9 \\
\hline No & 25 & 78.1 \\
\hline \multicolumn{3}{|l|}{ History of physical illness } \\
\hline Yes & 8 & 25.0 \\
\hline No & 24 & 75.0 \\
\hline \multicolumn{3}{|l|}{ History of psychiatric illness } \\
\hline Yes & 4 & 12.5 \\
\hline No & 28 & 87.5 \\
\hline BDI score & 11 & $1-27$ \\
\hline \multicolumn{3}{|l|}{ BDI score group } \\
\hline High $(\geq 17)$ & 13 & 40.6 \\
\hline Low $(<17)$ & 19 & 59.4 \\
\hline
\end{tabular}

\begin{tabular}{|c|c|c|c|c|}
\hline \multirow{2}{*}{ COPE subscales } & \multirow{2}{*}{$\begin{array}{l}\text { Median } \\
\text { (range) }\end{array}$} & \multirow{2}{*}{$\begin{array}{l}\text { Most frequent use } \\
\mathrm{n}(\%)\end{array}$} & \multicolumn{2}{|c|}{$\begin{array}{l}\text { Correlation analysis with BDI } \\
\text { score }\end{array}$} \\
\hline & & & $r$ & $\mathrm{p}$ \\
\hline Problem-focused coping & $67.0(41.0-72.0)$ & $29(90.6)$ & -0.400 & 0.023 \\
\hline Active coping & $15.0(9.0-16.0)$ & $10(31.3)$ & -0.429 & 0.014 \\
\hline Restraint & $9.5(5.0-13.0)$ & $0(0.0)$ & -0.501 & 0.004 \\
\hline Planning & $11.0(7.0-16.0)$ & $4(12.5)$ & -0.153 & 0.402 \\
\hline Seeking instrumental social support & $14.5(6.0-16.0)$ & $9(28.1)$ & -0.367 & 0.039 \\
\hline Supression of competing activities & $14.0(10.0-16.0)$ & $10(31.3)$ & -0.050 & 0.786 \\
\hline Emotional-focused coping & $43.5(41.0-72.0)$ & $2(6.3)$ & -0.144 & 0.433 \\
\hline Positive reinterpretation and growth & $5.5(4.0-11.0)$ & $0(0.0)$ & 0.111 & 0.544 \\
\hline Religious coping & $16.0(9.0-16.0)$ & $28(87.5)$ & -0.078 & 0.670 \\
\hline Humor & $6.0(4.0-10.0)$ & $0(0.0)$ & -0.189 & 0.301 \\
\hline Seeking emotional social support & $6.0(4.0-12.0)$ & $0(0.0)$ & 0.134 & 0.463 \\
\hline Acceptance & $11.0(6.0-14.0)$ & $0(0.0)$ & -0.240 & 0.185 \\
\hline Less useful coping styles & $55.5(44.0-65.0)$ & $1(3.1)$ & -0.147 & 0.422 \\
\hline Behavioral disengagement & $13.0(7.0-15.0)$ & $0(0.0)$ & -0.179 & 0.326 \\
\hline Substance use (Alcohol/drug use) & $4.0(4.0-5.0)$ & $0(0.0)$ & -0.344 & 0.054 \\
\hline Denial & $13.0(7.0-16.0)$ & $6(18.8)$ & 0.042 & 0.821 \\
\hline Mental disengagement & $13.0(7.0-15.0)$ & $0(0.0)$ & -0.089 & 0.627 \\
\hline Focus on andventing of emotions & $14.0(10.0-16.0)$ & $8(25.0)$ & -0.167 & 0.362 \\
\hline
\end{tabular}




\section{Discussion}

In this study, we found that mothers of children with CHD used problem-focused coping more frequently. Conversely, emotionalfocused and less useful coping attitudes scale scores were less used. In addition, religious coping attitude from the subscales was found to be the most frequently used coping method. There was a negative correlation between the problem-focused coping attitude total score and the BDI total score. There was also a negative correlation between the scores of active coping, restraint, and seeking instrumental social support subscales and BDI score.

In the course of many chronic diseases, anxieties and fears about the child's health are stressors for the family. Exacerbations and recurrent hospitalizations can lead to changes in family lifestyle, over-control of the child, and overprotective attitudes [14]. Numerous trials have revealed that the need for psychiatric help and mental problems increase in the parents of children with chronic diseases, especially mothers are at higher risk of experiencing emotional and marital problems [15]. Parents' coping skills are important as they determine the adaptation of the child and family to the disease [14]. Thopmson et al., in their study on mothers of children and adolescents with cystic fibrosis and sickle cell disease, showed that mothers who use palliative coping methods to cope with disease-related stress experience more adjustment problems than those who use adaptive coping strategies [16]. In a study conducted in families of children with thalassemia, psychiatric symptoms were more common in mothers with avoidant coping skills such as fatalism and passivity, and active coping methods were associated with less distress index [17].

Family functionality and coping attitudes were associated with treatment compliance [18]. It is essential to support the families and mothers psychosocially, active coping methods, and positive characteristics during outpatient follow-up and hospitalization [18]. Few studies in the literature investigate coping methods used in mothers of children with CHD and their relationship with psychiatric symptoms. Our study is the first study that draws attention to this issue in our country.

There are very few studies in the literature investigating coping attitudes in mothers of infants with a CHD. In a study conducted with the Brief Cope Inventory in the mothers of 56 infants diagnosed with single ventricle during pregnancy, it was found that the postnatal Brief Cope Inventory had higher positive reframing scores, early palliative care reduced maternal anxiety, positive reframing of the mother, and improved communication and family relations [19]. Previous studies have shown that mothers with infants with $\mathrm{CHD}$ have higher rates of depression and anxiety symptoms [20]. It has been pointed out that CHD is a disease that increases the family burden and that both individual and family-based approaches are needed to provide psychological support to children with CHD and their parents [21, 22]. A psychosocial intervention program, developed through a study whose ultimate aim was to teach mothers active, generalizable, problem-solving strategies to address existing concerns about having a child with $\mathrm{CHD}$, has been shown to have a positive impact on infants and mothers [22]. Moderate improvement in growth and positive reinterpretation was demonstrated in this parent-infant intervention study [19].

In a study conducted in families of children diagnosed with autism it was shown that the most frequently used coping style was problem-focused [23]. In another study, the effect of coping strategies on the well-being of mothers of children with autism spectrum disorder (ASD) was investigated [24]. Low levels of emotion-focused coping and high levels of problem-focused coping in mothers were associated with better maternal health, independent of the child's symptomatology level [24]. The results of studies investigating coping attitudes in families of children with other chronic diseases mentioned above support our study results. In a study that included 29 children with a chronic illness and their mothers, a strong correlation was found between the coping styles that disrupted the adjustment of the COPE inventory and the total score of the Child and Adolescent Behaviour Assessment Scale ( $r=0.56, p=0.009)$ [25].

In our study, the more frequent use of problem-focused coping methods such as active coping, seeking instrumental social support, and restraint coping methods may indicate mothers of children with CHD to overcome the challenging situation or reduce its effects and adapt. It can be thought that problemfocused coping methods make it easier for mothers of children with CHD to adapt to the disease and, therefore, positively affect the care to be given to the child. The more frequent use of problem-focused coping methods by the mothers of the children in our research group may indicate an effort to adapt and find solutions to this chronic and uncertain disease.

The most commonly used coping style in our study population was religion coping, without any correlation with the BDI total score. We thought that this was not correlated with depression scores as a cultural feature. Therefore, we think that this result is related to the cultural characteristics of Turkish community rather than being a meaningful scientific finding. 
The main limitation of our study is that it was conducted in a single center and with a limited number of participants. Another limitation of our study is the absence of a control group (i.e., parents of healthy children or children with different congenital diseases).

\section{Conclusion}

Problem-focused coping may be a protective factor against depression in individuals with relatives with severe or fatal diseases. It is essential to focus on the family in the followup and treatment of children with CHD and to develop interventions to protect the mental health of mothers who are in the position of primary caregivers of children.

Studies with a larger number of participants with control groups and multi-center studies can both increase the statistical power and reveal a difference between the different populations regarding coping attitudes in mothers. New studies are needed to evaluate the effectiveness of interventions that can protect parents of children with lifethreatening diseases such as CHD from psychiatric diseases.

\section{Declaration of conflict of interest}

The authors received no financial support for the research and/or authorship of this article. There is no conflict of interest.

\section{References}

1. Denniss DL, Sholler GF, Costa DSJ et al. Need for Routine Screening of Health-Related Quality of Life in Families of Young Children with Complex Congenital Heart Disease. The Journal of pediatrics 2019; 205: 21-8.

2. van der Linde $D$, Konings EE, Slager MA et al. Birth prevalence of congenital heart disease worldwide: a systematic review and meta-analysis. Journal of the American College of Cardiology 2011; 58: 2241-7.

3. Cantwell-Bartl AM, Tibballs J. Psychosocial experiences of parents of infants with hypoplastic left heart syndrome in the PICU. Pediatric critical care medicine : a journal of the Society of Critical Care Medicine and the World Federation of Pediatric Intensive and Critical Care Societies 2013; 14: 869-75.

4. Sood E, Karpyn A, Demianczyk AC et al. Mothers and Fathers Experience Stress of Congenital Heart Disease Differently: Recommendations for Pediatric Critical Care. Pediatric critical care medicine : a journal of the Society of Critical Care Medicine and the World Federation of Pediatric Intensive and Critical Care Societies 2018; 19: 626-34.
5. Harvey KA, Kovalesky A, Woods RK et al. Experiences of mothers of infants with congenital heart disease before, during, and after complex cardiac surgery. Heart \& lung : the journal of critical care 2013; 42: 399-406.

6. Re J, Dean S, Menahem S. Infant cardiac surgery: mothers tell their story: a therapeutic experience. World journal for pediatric \& congenital heart surgery $2013 ; 4:$ 278-85.

7. Golfenshtein N, Srulovici E, Deatrick JA. Interventions for Reducing Parenting Stress in Families With Pediatric Conditions: An Integrative Review. Journal of family nursing 2016; 22: 460-92.

8. Davis CC, Brown RT, Bakeman R et al. Psychological adaptation and adjustment of mothers of children with congenital heart disease: stress, coping, and family functioning. Journal of pediatric psychology 1998; 23: 219-28.

9. Folkman S, Lazarus RS, Gruen RJ et al. Appraisal, coping, health status, and psychological symptoms. Journal of personality and social psychology 1986; 50: 571-9.

10. Carver CS, Scheier MF, Weintraub JK. Assessing coping strategies: a theoretically based approach. Journal of personality and social psychology 1989; 56: 267-83.

11. Beck AT, Ward $\mathrm{CH}$, Mendelson $M$ et al. An inventory for measuring depression. Arch Gen Psychiatry 1961; 4: 561-71.

12. Hisli N. Beck depresyon envanterinin universite ogrencileri icin gecerliligi, guvenilirligi. (A reliability and validity study of Beck Depression Inventory in a university student sample). J Psychol 1989; 7: 3-13.

13. Agargun $M$, Beşiroğlu $L$, Kıran ÜK et al. The psychometric properties of the COPE inventory in Turkish sample: A preliminary research. Anatolian Journal of Psychiatry 2005; 6.

14. Melnyk BM, Feinstein NF, Moldenhouer Z et al. Coping in parents of children who are chronically ill: strategies for assessment and intervention. Pediatric nursing 2001; 27: 548-58.

15. Wallander JL, Varni JW. Effects of pediatric chronic physical disorders on child and family adjustment. Journal of child psychology and psychiatry, and allied disciplines 1998; 39: 29-46.

16. Thompson RJ, Jr., Gil KM, Gustafson KE et al. Stability and change in the psychological adjustment of mothers of children and adolescents with cystic fibrosis and sickle cell disease. Journal of pediatric psychology 1994; 19: 171-88. 
17. Rao P, Pradhan PV, Shah H. Psychopathology and coping in parents of chronically ill children. Indian journal of pediatrics 2004; 71: 695-699.

18. Geist R, Grdisa V, Otley A. Psychosocial issues in the child with chronic conditions. Best practice \& research Clinical gastroenterology 2003; 17: 141-52.

19. Hancock HS, Pituch K, Uzark K et al. A randomised trial of early palliative care for maternal stress in infants prenatally diagnosed with single-ventricle heart disease. Cardiology in the young 2018; 28: 561-70.

20. Solberg $\varnothing$, Dale MT, Holmstrøm $\mathrm{H}$ et al. Long-term symptoms of depression and anxiety in mothers of infants with congenital heart defects. Journal of pediatric psychology 2011; 36: 179-87.

21. Landolt MA, Ystrom E, Stene-Larsen $\mathrm{K}$ et al. Exploring causal pathways of child behavior and maternal mental health in families with a child with congenital heart disease: a longitudinal study. Psychological medicine 2014; 44: 3421-33.
22. McCusker CG, Doherty NN, Molloy B et al. A controlled trial of early interventions to promote maternal adjustment and development in infants born with severe congenital heart disease. Child: care, health and development 2010; 36: 110-7.

23. Lin CR, Tsai YF, Chang HL. Coping mechanisms of parents of children recently diagnosed with autism in Taiwan: a qualitative study. Journal of clinical nursing 2008; 17: 2733-40.

24. Smith LE, Seltzer MM, Tager-Flusberg $\mathrm{H}$ et al. A comparative analysis of well-being and coping among mothers of toddlers and mothers of adolescents with ASD. Journal of autism and developmental disorders 2008; 38: 876-89.

25. Cop E, Dinç G, Kultur E. Coping Styles of Mothers of Children with Chronic Diseases and Their Relationship with Psychiatric Symptoms: A Preliminary Report. Turkish Journal of Pediatric Disease 2016. 